\title{
Improving biodegradability of clopyralid wastes by photoelectrolysis: the role of
}

\section{the anode material}

Géssica O. S. Santos, ${ }^{\mathrm{a}, \mathrm{b}, \mathrm{c}}$, Isabelle M. D. Gonzaga ${ }^{\mathrm{a}, \mathrm{b}, \mathrm{c}}$, Katlin I. B. Eguiluz ${ }^{\mathrm{a}, \mathrm{b}}$; Giancarlo R. SalazarBanda $^{\mathrm{a}, \mathrm{b}}$; Cristina Saez ${ }^{\mathrm{c}}$; Manuel A. Rodrigo ${ }^{\mathrm{c}, ~ *}$

${ }^{a}$ Electrochemistry and Nanotechnology Laboratory, Research and Technology Institute - ITP, Aracaju, SE, Brazil

${ }^{b}$ Processes Engineering Post-graduation-PEP, Universidade Tiradentes, 49037-580 Aracaju, SE, Brazil

${ }^{c}$ Department of Chemical Engineering, Universidad de Castilla-La Mancha, Campus Universitario s/n, 13071 Ciudad Real, Spain 11

2

\section{Abstract}

In this work, the removal of the non-readily biodegradable herbicide clopyralid by electrochemical (EC) and photoelectrochemical (PhEC) oxidation with different anode materials were conducted looking to improve not only its oxidation but also its biodegradability. First, in order to find out optimal conditions, it was carried out EC and PhEC degradations in chloride medium, at current densities ranging from 30 to $100 \mathrm{~mA} \mathrm{~cm}{ }^{-2}$ during $1 \mathrm{~h}\left(0.8-2.7 \mathrm{~A} \mathrm{~h} \mathrm{~L}^{-1}\right)$, using as anodes MMO$\mathrm{RuO}_{2} \mathrm{TiO}_{2}, \mathrm{MMO}-\mathrm{RuO}_{2} \mathrm{IrO}_{2}, \mathrm{MMO}-\mathrm{IrO}_{2} \mathrm{Ta}_{2} \mathrm{O}_{5}$ and boron-doped diamond (BDD). Results show better efficiencies on clopyralid removal for $\mathrm{MMO}-\mathrm{RuO}_{2} \mathrm{IrO}_{2}$ and $\mathrm{BDD}$ anodes at lower current densities. Then, the influence of all anodes on clopyralid transformation was evaluated, extending the electrolysis and photoelectrolysis for $8 \mathrm{~h}$ applying $30 \mathrm{~mA} \mathrm{~cm}{ }^{-2}\left(6.4 \mathrm{~A} \mathrm{~h} \mathrm{~cm}^{-3}\right)$. At these conditions, better outcomes are observed for PhEC degradation, where complete pollutant removal is attained for BDD anode and $88.7 \%$ for $\mathrm{MMO}-\mathrm{RuO}_{2} \mathrm{IrO}_{2}$, while COD removal is $47.7 \%$ for MMO and $43.1 \%$ for BDD anode. Then, short-term biodegradability tests, conducted for EC and PhEC processes, pointed out that $\mathrm{MMO}-\mathrm{RuO}_{2} \mathrm{TiO}_{2}$ is the most promising anode material, being capable of improving 

7

biodegradability in $48.2 \%$ and $53 \%$ for EC and PhEC degradation, respectively. The toxicity of treated solutions using $\mathrm{MMO}-\mathrm{RuO}_{2} \mathrm{TiO}_{2}$ and $\mathrm{BDD}$ anodes in both $\mathrm{EC}$ and $\mathrm{PhEC}$ degradation were compared, employing the inhibitory effect in the bioluminescence of marine bacteria Vibrio Fisheri. Toxicity assessments show that toxicity significantly reduces by using the $\mathrm{MMO}-\mathrm{RuO}_{2} \mathrm{TiO}_{2}$ in $\mathrm{NaCl}$ and $\mathrm{Na}_{2} \mathrm{SO}_{4}$ medium for both processes. Finally, this study demonstrates that photoelectrolysis with MMO anodes was the most effective strategy in order to increase biodegradability in chloride media, as well as to reduce the toxicity of the treated waste.

Keywords: Electrolysis; photoelectrolysis; clopyralid; BDD; MMO.

\section{Highlights}

(1)

- Clopyralid can be removed using electrolysis and photoelectrolysis

- Degradation is more efficient at low current densities using $\mathrm{MMO}-\mathrm{RuO}_{2} \mathrm{TiO}_{2}$ anode

- Readily biodegradability could be doubled by photoelectrolysis with $\mathrm{MMO}-\mathrm{RuO}_{2} \mathrm{TiO}_{2}$

- Treated solutions with $\mathrm{MMO}-\mathrm{RuO}_{2} \mathrm{TiO}_{2}$ reduced their toxicity. Not the case of using BDD . .

*Author to whom all correspondence should be addressed: manuel.rodrigo@uclm.es 


\section{Introduction}

Contamination of water associated with the use of pesticides and fertilizers is an issue of growing concern because of the potential risk to both the environment and human health [1]. Clopyralid (3,6dichloro-2-pyridine-carboxylic acid) is an organochlorinated herbicide, persistent, and not readily biodegradable $[2,3]$. Due to its high solubility in water, clopyralid has been detected very frequently in the environment and even in drinking water [4].

Nowadays, biological treatment is the most popular method to treat almost any type of wastewater, possessing essential advantages as compared with other technologies and being cost-effective [5]. Unfortunately, biological methods are not always practical for treating wastewater polluted with complex anthropogenic organic molecules (such as chlorinated organic compounds) [6,7]. Therefore, it is of great importance to search efficient treatments capable of removing this type of contaminants from water resources [8]. In this context, electrochemical advanced oxidation processes (EAOPs) are attracting attention because they are efficient to achieve the destruction of contaminants, and, depending on the operational conditions, they can attain the complete mineralization [9-11]. As it is well-known, anode material plays a vital role in EAOPs: non-active anodes comprise materials with high oxygen evolution overpotentials that favor the total oxidation of organics to $\mathrm{CO}_{2}$; active anodes include materials with low oxygen evolution overpotential, that permit mainly the transformation of organics into other more oxidized organic metabolites $[12,13]$. The mixed metal oxides (MMOs) anodes belong to this latter category. They are made of a mixture of metallic oxides supported on less expensive materials such as titanium and can be produced by diverse techniques [14-17]. Opposite, BDD is a well-known non-active anode that exhibits weak surface interactions with hydroxyl radicals [18], favoring mineralization of organics.

Another important point to be addressed is the oxidants that can be formed depending on the salts that are present in the electrolytic solution. In particular, the occurrence of chloride is significant. This anion can be found in most water and wastewater sources, exhibiting a pivotal role in the electrolysis of actual wastes. In the electrolysis of wastewater containing chloride, chlorine and 
hypochlorite are expected to be produced. However, the main problems associated with the chloride ions are the formation of organochlorinated species and the production of chlorates and perchlorates. Because of this occurrence, toxicity is also an important parameter and must be accompanied in order to ensure safe treated solutions $[4,9,19]$.

The main drawback of the electrochemical-based process is the energy required [20], which motivates research towards improvements in this approach in order to be more energy-efficient and costeffective $[21,22]$. Thus, the proposal of a coupled process to be applied as a pre-treatment step prior to the usually cheaper biological treatment has been a topic of great interest $[5,23,24]$.

Hence, in this work, the degradation of clopyralid wastes by the electrochemical and photoelectrochemical processes was investigated. The influence of the different types of anodes materials (i.e., distinct MMOs and BDD) on the biodegradability and toxicity of the final treated wastes was studied. In both processes, we focused on the transformation of the contaminant into more readily biodegradable compounds, and not on the total mineralization.

\section{Materials and Methods}

\subsection{Chemicals}

Clopyralid (3,6-Dichloro-pyridine-2carboxylic acid) (Sigma Aldrich), sodium chloride (Panreac), anhydrous sodium sulfate (Panreac), sodium hydroxide (Sigma Aldrich) and sulfuric acid (Sigma Aldrich) were of analytical grade and used as received. These reagents were used to make the synthetic wastewater and for $\mathrm{pH}$ adjustment. Both methanol HPLC grade and formic acid (SigmaAldrich) were used in the mobile phase. All solutions were prepared using high-purity water (Millipore Milli-Q system, resistivity: $18.2 \mathrm{M} \Omega \mathrm{cm}$ at $25^{\circ} \mathrm{C}$.

\subsection{Preparation of the electrodes}

The $\mathrm{Ti} / \mathrm{RuO}_{2}-\mathrm{TiO}_{2}$ and $\mathrm{Ti} / \mathrm{RuO}_{2}-\mathrm{IrO}_{2}$ anodes were prepared by the thermal decomposition of polymeric precursors (or Pechini method), using $\mathrm{CO}_{2}$ laser and microwave heating, respectively. To 
obtain the precursor solutions, ruthenium chloride (III) hydrate $\left(\mathrm{RuCl}_{3} \cdot \mathrm{xH}_{2} \mathrm{O}, 99.99 \%\right)$, iridium chloride (III) hydrate ( $\left.\mathrm{IrCl}_{3} \cdot \mathrm{xH}_{2} \mathrm{O}, 99.0 \%\right)$, titanium (IV) butoxide (97.0 \%) and ethylene glycol (EG) (99.8\%), were purchased from Sigma Aldrich $^{\circledR}$, and anhydrous citric acid (CA) (99.5\%), from Vetec $^{\circledR}$. First, Ti plates, with a geometric area of $4 \mathrm{~cm}^{2}$, were polished, and then rinsed with ultrapure water. After that, they were immersed into boiling hydrochloric acid ( $\mathrm{HCl}, 38.0 \%$ from $\mathrm{Neon}^{\circledR}$ ) solution $(20 \% \mathrm{v} / \mathrm{v})$ for $15 \mathrm{~min}$, followed by immersion into boiling oxalic acid $\left(99.5 \%\right.$, from Vetec $\left.^{\circledR}\right)$ solution $(10 \% \mathrm{v} / \mathrm{v})$, and then finally rinsed with ultrapure water. In order to obtain the precursor solutions, the ruthenium chloride and titanium butoxide were weighed in the molar ratio of $0.3 / 0.7$ $(\mathrm{Ru} / \mathrm{Ti})$; whereas the ruthenium and iridium chloride were weighed in the molar ratio of $0.5 / 0.5$ ( $\mathrm{Ru} / \mathrm{Ir})$, to be subsequently dissolved in the EG:CA solution (10:3).

The solutions were spread over the Ti surface by brushing. For the laser heating employed to obtain the $\mathrm{Ti} / \mathrm{RuO}_{2}-\mathrm{TiO}_{2}$ anode, the strategy was to increase the temperature almost instantaneously to reach $400{ }^{\circ} \mathrm{C}$ for $40 \mathrm{~s}$ and then cooled immediately to room temperature [16]. For the $\mathrm{Ti} / \mathrm{RuO}_{2^{-}}$ $\mathrm{IrO}_{2}$ anodes, the heating consisted of a hybrid process [25] where the electrodes were placed at 45 degrees inside the $\mathrm{SiC}$ (used as susceptor due to its high dielectric loss) in order to be irradiated for 23 min until reaching $350^{\circ} \mathrm{C}$. After that, the irradiation was stopped, and the electrodes were cooled. The Ti supports were coated with successive layers of the oxides until they reached a mass density of $1.2 \mathrm{mg} \mathrm{cm}^{-2}$, as determined by weight difference.

\subsection{Experimental set-up}

The electrochemical (EC) and photoelectrochemical oxidation (PhEC) experiments were conducted in a one-compartment electrochemical cell. The capacity of the cell was $0.15 \mathrm{~L}$ containing $100 \mathrm{mg}$ $\mathrm{L}^{-1}$ of clopyralid at natural $\mathrm{pH}$ (3.4). Aqueous sodium chloride $\left(3.7 \mathrm{~g} \mathrm{~L}^{-1}\right)$ was used as the supporting electrolyte. Some experiments using $\mathrm{Na}_{2} \mathrm{SO}_{4}\left(3.0 \mathrm{~g} \mathrm{~L}^{-1}\right)$ at the same ionic strength were performed. The working electrodes were the different MMO anodes, namely $\mathrm{MMO}-\mathrm{RuO}_{2} \mathrm{TiO}_{2}$ (laser-prepared), MMO- $\mathrm{RuO}_{2} \mathrm{IrO}_{2}$ (microwave-prepared), an $\mathrm{MMO}-\mathrm{IrO}_{2} \mathrm{Ta}_{2} \mathrm{O}_{5}$ (supplied by Tiaano ${ }^{\circledR}$ ) and a BDD 
(supplied by Adamant technologies). The MMOs consist of metallic support of titanium, where the coatings proportions are 70:30 for $\mathrm{RuO}_{2} \mathrm{TiO}_{2}, 50: 50$ for $\mathrm{MMO}-\mathrm{RuO}_{2} \mathrm{IrO}_{2}$, and 70:30 for the commercial MMO-IrO $\mathrm{Ta}_{2} \mathrm{O}_{5}$. BDD anode was a thin-film deposited on $\mathrm{p}-\mathrm{Si}$ with $8000 \mathrm{ppm}$ of boron doping $\left(\mathrm{sp}^{3} / \mathrm{sp}^{2}: 80\right)$. All anodes had a geometric exposed area of $4.0 \mathrm{~cm}^{2}$. The cathode was a platinum wire, and the reference electrode was $\mathrm{AgCl}$.

The applied current density ranged from 30 to $100 \mathrm{~mA} \mathrm{~cm}$ provided by potentiostat/galvanostat 302N. For the photoelectrochemical (PhEC) oxidation, a 9 W UV-C lamp (254 nm) was directly immersed into the electrochemical cell. All solutions were stirred with a magnetic agitator during experiments. Aliquots were taken during each experiment at different time intervals and then filtered through $0.45 \mu \mathrm{m}$ filters for posterior analysis.

\subsection{Analytical Methods}

The clopyralid removal was monitored using HPLC (Agilent 1260, ZORBAX Eclipse C18 analytical column). The mobile phase consisted of $30 \%$ methanol/70\% water with $0.1 \%$ of formic acid (flow rate: $1.0 \mathrm{~cm}^{3} \mathrm{~min}^{-1}$ ). The DAD detection wavelength was $280 \mathrm{~nm}$, the temperature was maintained at $25{ }^{\circ} \mathrm{C}$, and the injection volume was $20 \mu \mathrm{L}$. Acids were identified by an HPLC equipped with a Zorbax SB-Aq, column $(4.6 \mathrm{~mm} \times 150 \mathrm{~mm})$. The mobile phase consisted of $4 \mathrm{mM} \mathrm{H}_{2} \mathrm{SO}_{4}$. The detection wavelength was fixed at $210 \mathrm{~nm}$. The intermediates were identified by comparison of their retention times with standard solutions. The measurements of cyclic voltammograms (CVs) and linear sweep voltammograms (LSVs) were performed by a potentiostat/galvanostat model PGTAT $302 \mathrm{~N}$. CVs were recorded at the potential interval from 0.0 to $1.3 \mathrm{~V}$ for the MMO and 0.0 to 3.0 in the case of BDD, while the LSVs were performed in the potential interval of 0.0 to $1.4 \mathrm{~V}$ for MMOs and 0.0 to 2.2 for BDD anode, at a scan rate of $0.01 \mathrm{mV} \mathrm{s}^{-1}$.

The instantaneous current efficiency (ICE) for the electrochemical oxidation was calculated from Eq. (1), where $(\mathrm{COD})_{\mathrm{t}}$ and $(\mathrm{COD})_{\mathrm{t}+\Delta \mathrm{t}}$ are the chemical oxygen demands at times $\mathrm{t}$ and $\mathrm{t}+\Delta \mathrm{t}$ (in $\mathrm{g} \mathrm{O}_{2}$ $\mathrm{L}^{-1}$ ), respectively, $\mathrm{I}$ is the current (in A), $\mathrm{F}$ is the Faraday constant $\left(96487 \mathrm{C} \mathrm{mol}^{-1}\right)$, and $\mathrm{V}$ is the 
solution volume (L) [26, 27]. The specific energy consumption (SEC) was calculated according to Eq (2), and volumetric energy consumption (VEC) according to Eq (3), where $\mathrm{E}_{\text {cell }}$ is the average cell voltage $(\mathrm{V})$.

$\operatorname{ICE}(\%)=\mathrm{F} \mathrm{V} \frac{(C O D)_{t}-(C O D)_{t+\Delta t}}{8 I \times \Delta t} \times 100$

$\operatorname{SEC}\left(\mathrm{kW} \mathrm{h} \mathrm{g}^{-1} \mathrm{COD}\right)=\frac{E_{c e l l} \mathrm{t}}{V(C O D)_{t^{-}}(C O D)_{0}}$

$\operatorname{VEC}\left(\mathrm{kW} \mathrm{h} \mathrm{L}^{-1}\right)=\frac{E_{c e l l} \mathrm{It}}{V}$

\subsection{Biodegradability tests}

For short-term biodegradability $\left(\mathrm{BOD}_{\mathrm{st}}\right)$, unacclimated activated sludge, taken from a local conventional wastewater treatment plant (WTTP) (Ciudad Real, Spain), was used in the biodegradability test. The sludge was maintained with sodium acetate $\left(100 \mathrm{mg} \mathrm{L}^{-1}\right)$ as carbon sources in the bioreactor at $21 \pm 3{ }^{\circ} \mathrm{C}$. The assays were conducted in a $100 \mathrm{~mL}$ beaker filled with $95 \mathrm{~mL}$ of activated sludge under continuous stirrer by magnetic bars. The dissolved oxygen (DO) concentration decay was measured with oximetry (WWR-OX4100H). Before biodegradability and toxicity analysis, $\mathrm{pH}$ values were adjusted to 7.0. Chemical oxygen demand (COD) analyses were conducted by using Spectroquant ${ }^{\circledR}$ test kits from Merck.

\subsection{Toxicity towards Vibrio fisheri}

The acute toxicity of initial and treated clopyralid synthetic solutions was measured with Microtox ${ }^{\circledR}$ by inhibition of bioluminescence of marine bacteria Vibrio fisheri according to the protocol indicated by the manufacturer. The osmotic control of the samples was adjusted prior to tests. The emitted bioluminesce was recorded for 5 and 15 min of exposure and compared to that of the blank sample.

\section{Results and Discussion}

\subsection{Electrochemical characterization}

Anode materials are of great importance in electrochemical oxidation, and anodes with different 
coatings are known to exhibit different electrocatalytic properties. Then, to further understand the electrochemical behavior of the anodes here studied, voltammetric curves of the $\mathrm{MMO}-\mathrm{RuO}_{2} \mathrm{TiO}_{2}$, MMO-IrO $\mathrm{RuO}_{2}, \mathrm{MMO}-\mathrm{IrO}_{2} \mathrm{Ta}_{2} \mathrm{O}_{5}$, and $\mathrm{BDD}$ anodes were recorded at a scan rate of $50 \mathrm{mV} \mathrm{s}^{-1}$ and LSV curves were recorded at $10 \mathrm{mV} \mathrm{s}^{-1}$ in $3.7 \mathrm{mg} \mathrm{L}^{-1} \mathrm{NaCl}$ solutions (Figure 1).

The voltammetric charge, $q^{*}$, obtained by the integration of the CVs between the oxygen and hydrogen evolution reactions, can be considered as a relative measurement of the electrochemically active surface area (EASA) of the anodes, and its values are collected in Table 1. The EASA reduces in the following order: $\mathrm{RuO}_{2} \mathrm{TiO}_{2}>\mathrm{RuO}_{2} \mathrm{IrO}_{2}>\mathrm{IrO}_{2} \mathrm{Ta}_{2} \mathrm{O}_{5}>\mathrm{BDD}$.

Note from LSV data (Figure 1e) that the oxygen evolution potential (OEP) increases according to the sequence $\mathrm{BDD}>\mathrm{IrO}_{2} \mathrm{Ta}_{2} \mathrm{O}_{5}>\mathrm{RuO}_{2} \mathrm{TiO}_{2} \approx \mathrm{RuO}_{2} \mathrm{IrO}_{2}$.

It is worth to point out that the LSV experiments where performed in a diluted chloride solution; then, the oxygen evolution is expected to occur concomitantly with the generation of chlorine gas [28]. The much higher OEP value for the BDD anodes, regardless of the electrolyte media, is well-known in the literature due to the "non-active" nature of this material, which favors the generation of large amounts of physisorbed hydroxyl radicals. However, considering that the MMO anodes are suitable catalysts for chlorine evolution, in the presence of $\mathrm{Cl}^{-}$ions, the use of these anodes for the generation of active chlorine is of interest in the sense of mediated oxidation. Thus, in order to enhance the active chlorine, these materials should mitigate the oxygen evolution reaction. At this point, note that although it is impossible to estimate the number of chlorine species produced with the voltammetry experiment, it is evident that the lower is the potential, the higher is the catalytic activity at a fixed current density. 

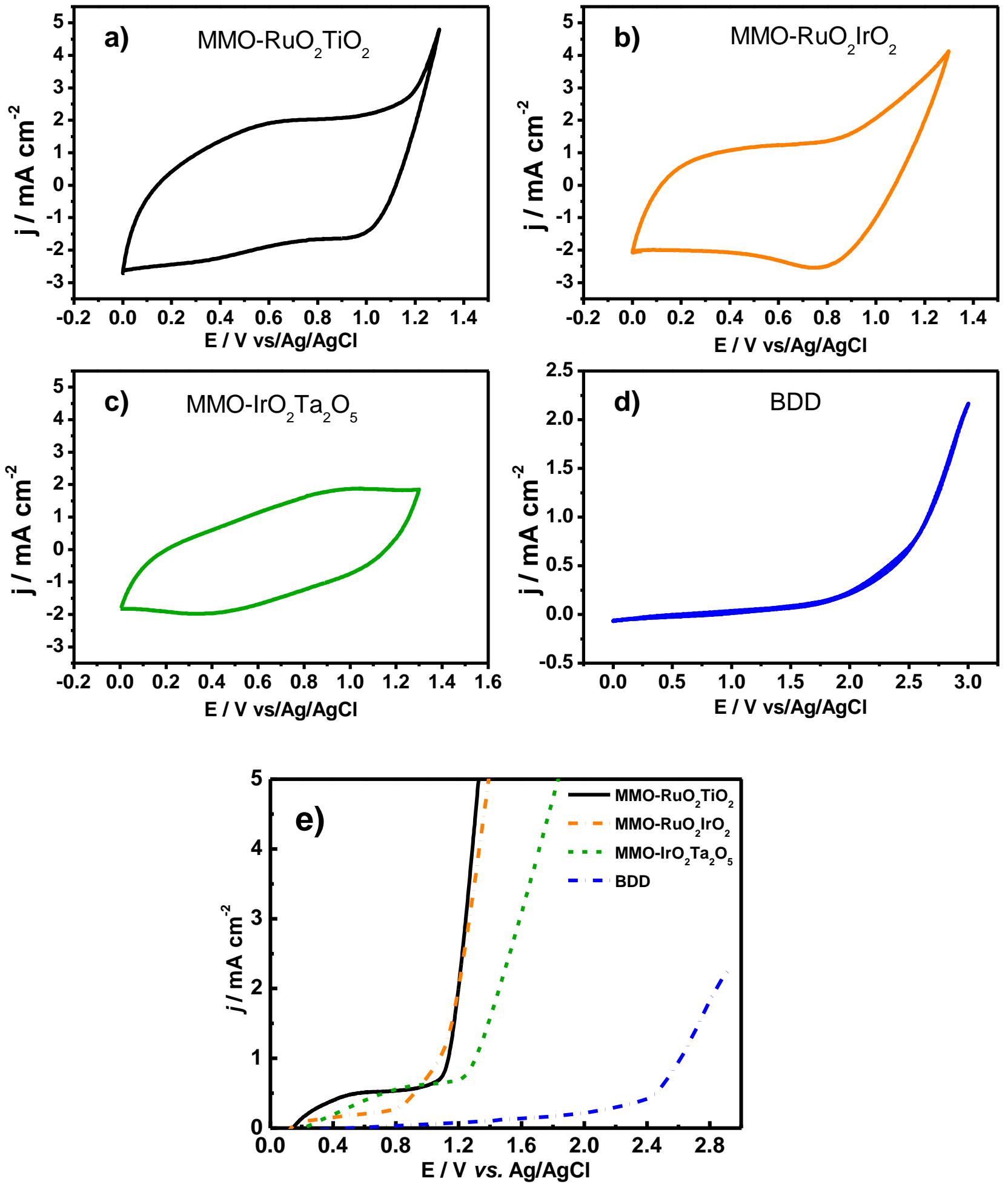

203 Figure 1. Cyclic voltammograms recorded at $50 \mathrm{mV} \mathrm{s}{ }^{-1}$ of $M M O-\mathrm{RuO}_{2} \mathrm{TiO}_{2}$ (a), $\mathrm{MMO}-\mathrm{RuO}_{2} \mathrm{IrO}_{2}$

(b) $\mathrm{MMO}-\mathrm{IrO}_{2} \mathrm{Ta}_{2} \mathrm{O}_{5}$ (c) $\mathrm{BDD}$ (d) in $\mathrm{NaCl} 3.7 \mathrm{~g} \mathrm{~L}^{-1}$ electrolyte and linear sweep voltammetry curves of the different anode materials recorded in at $10 \mathrm{mV} \mathrm{s}^{-1}$. 
209 Table 1. Voltammetric charge $\left(q^{*}\right)$ and the OEP values found for different anodes studied.

\begin{tabular}{|c|c|c|}
\hline Anode & $\mathbf{q}^{*} / \mathrm{mC} \mathrm{cm}^{-2}$ & OEP / V vs. Ag/AgCl \\
\hline $\mathrm{MMO}-\mathrm{RuO}_{2} \mathrm{TiO}_{2}$ & 77.13 & 1.13 \\
\hline $\mathrm{MMO}-\mathrm{RuO}_{2} \mathrm{IrO}_{2}$ & 72.80 & 1.07 \\
\hline $\mathrm{MMO}-\mathrm{IrO}_{2} \mathrm{Ta}_{2} \mathrm{O}_{5}$ & 57.40 & 1.32 \\
\hline BDD & - & 2.45 \\
\hline
\end{tabular}

210

211

212

\subsection{Electrochemical degradation of clopyralid}

It is well-known that EC results are dependent on the applied current density [29]. Thus, the simultaneous selection of the anode material and the current density operating conditions is of great importance in order to select the best option capable of transforming the herbicide into more biodegradable molecules. The comparison of anodes helps to select the most suitable material and condition envisaging a combination with biological treatment.

Figure 2 shows the clopyralid removal in chloride medium by electrochemical oxidation at MMO-RuO $\mathrm{TiO}_{2}, \mathrm{MMO}-\mathrm{RuO}_{2} \mathrm{IrO}_{2}, \mathrm{MMO}-\mathrm{IrO}_{2} \mathrm{Ta}_{2} \mathrm{O}$, and BDD anodes at current densities of $30 \mathrm{~mA}$ $\mathrm{cm}^{-2}$ (Figure 2a), $50 \mathrm{~mA} \mathrm{~cm}^{-2}$ (Figure 2b) and $100 \mathrm{~mA} \mathrm{~cm}^{-2}$ (Figure 2c) for $1 \mathrm{~h} \mathrm{in} \mathrm{NaCl} 3.7 \mathrm{~g} \mathrm{~L}^{-1}$. It is important to point out that any of the experimental conditions tested result in the complete removal of clopyralid, as expected, because of the low applied electric charge per unit volume (ranging from 0.8 to $2.7 \mathrm{~A} \mathrm{~h} \mathrm{~L}^{-1}$ ). However, these experiments help to clarify the most suitable current densities, as well as the behavior of different anodes employed. Figure 2 shows that the increase in the current density does not significantly improve the clopyralid removal, which can be due to side reactions, such as oxygen evolution occurring at the anode surface (Eq. 4). 
Plotting the clopyralid removal as a function of applied electric charge per unit volume, Q

$230\left(\mathrm{Ah} \mathrm{L}^{-1}\right)$ (Figure S1) for all the anodes studied, it can be seen that for the same electric charge passed,

231 the oxidation reached is not the same. A clear improvement occurs by lowering the current density, 232 which indicates that the process is under mass-transport control, confirming that secondary reactions 233 (such as oxygen evolution) are involved, then decreasing the process efficiency as already pointed 234 out in previous works [30-32].

235 Regarding the influence of the different anode materials tested on the removal performance at 236 different current densities, it is observed that the $\mathrm{MMO}-\mathrm{RuO}_{2} \mathrm{TiO}_{2}$ is as efficient as the $\mathrm{BDD}$. Thus, $30 \mathrm{~mA} \mathrm{~cm}^{-2}\left(0.8 \mathrm{~A} \mathrm{~h} \mathrm{~L}^{-1}\right)$, seems to be the most suitable current density found, showing a clopyralid removal of $17.1 \%$ of $16.6 \%$, for MMO and BDD respectively.

Further analysis from instantaneous current efficiency (ICE) and volumetric energy consumption (VEC) data obtained for the electrochemical oxidation using the different anodes materials tested (Figure S2) confirm that the application of lower current density results in higher ICE and lower VEC.

The values found for clopyralid removal for $\mathrm{MMO}-\mathrm{RuO}_{2} \mathrm{TiO}_{2}$ can be explained in terms of different mechanisms involving the formation of reactive chlorine species. Chlorine can be generated on the anode surface (Eq. 5) and can be transformed in bulk into hypochlorous acid/hypochlorite. (Eqs. 6-7).

$$
\mathrm{Cl}_{2}+\mathrm{H}_{2} \mathrm{O} \rightarrow \mathrm{HClO}+\mathrm{Cl}^{-}+\mathrm{H}^{+}
$$

$$
\mathrm{HClO} \rightarrow \mathrm{ClO}^{-}+\mathrm{H}^{+}
$$

251 in co-existence with chlorine species, successively oxidize $\mathrm{Cl}^{-}$to different oxochlorinated compounds by different reactions shown in Eqs. (8-12), which leads to the formation of non-useful and hazardous chlorate and perchlorate. 
$256 \mathrm{Cl}^{-}+{ }^{\bullet} \mathrm{OH} \rightarrow \mathrm{ClO}^{-}+\mathrm{H}^{+}+\mathrm{e}^{-}$

$\mathrm{ClO}^{-}+{ }^{\bullet} \mathrm{OH} \rightarrow \mathrm{ClO}_{2}^{-}+\mathrm{H}^{+}+\mathrm{e}^{-}$

$\mathrm{ClO}_{2}^{-}+{ }^{\bullet} \mathrm{OH} \rightarrow \mathrm{ClO}_{3}^{-}+\mathrm{H}^{+}+\mathrm{e}^{-}$

Results from COD removal show slight removals for all anodes at these conditions (i.e., low applied 262 electric charge ranging from 0.8 to $2.7 \mathrm{~A} \mathrm{~h} \mathrm{~L}^{-1}$ ), which indicates that more extended experiments are 263 necessary to attain a higher degree of contaminant transformation.

264

265
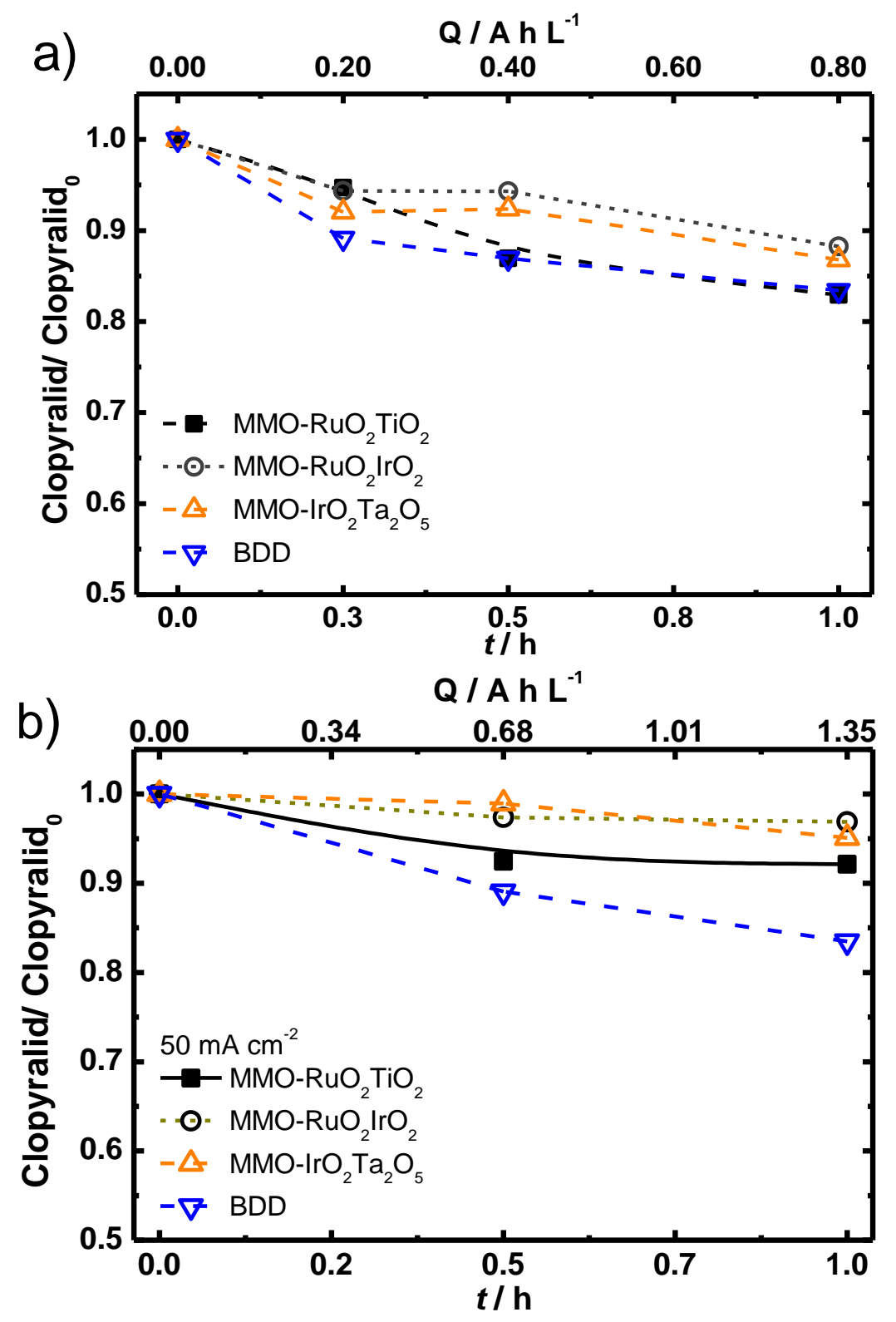


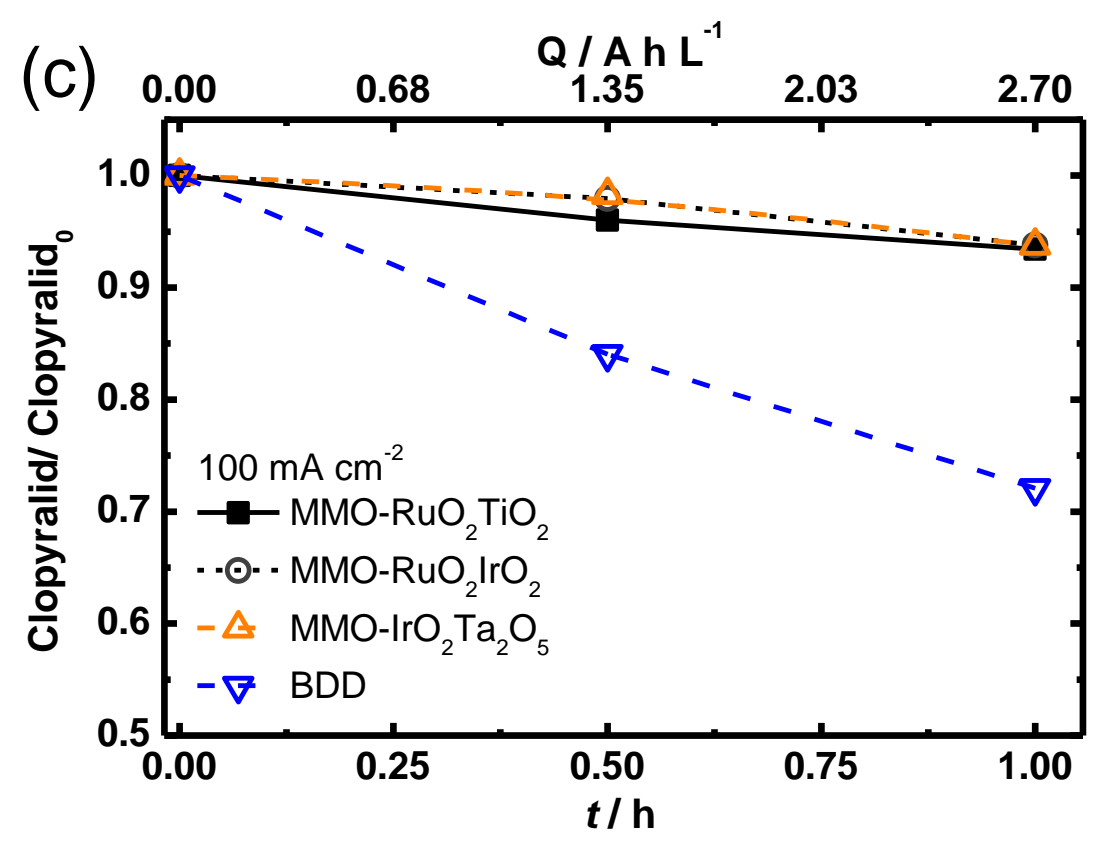

\subsection{Photoelectrochemical degradation}

The system was irradiated with 9 W UV-C light $(254 \mathrm{~nm})$, looking for reaching higher efficiencies in the clopyralid removal. Figure 3 shows the clopyralid removal in the photoelectrochemical (PhEC) degradation at current densities ranging from 30 to $100 \mathrm{~mA} \mathrm{~cm}{ }^{-2}$ in $\mathrm{NaCl} 3.7 \mathrm{~g} \mathrm{~L}^{-1}$ for MMO$\mathrm{RuO}_{2} \mathrm{TiO}_{2}$ and BDD anodes. Regarding current density, the same trend previously seen in the EC degradation is observed for the PhEC with $\mathrm{MMO}-\mathrm{RuO}_{2} \mathrm{TiO}_{2}$, i.e., the higher is the current density applied, the lower is the process efficiency. On the other hand, for PhEC-BDD, the trend is opposite to the previously observed for EC, where the higher is the applied current, the higher is the removal, and under irradiation with 9 W UV-C light at higher current densities, the efficiency of the process decreases.

The plot of clopyralid removal as a function of the applied electric charge per unit volume for the different anodes materials tested at different current densities (Figure S1) clearly shows that for the same applied electric charge, there is no improvement by increasing the current. On the other hand, 
$\mathrm{PhEC}$ process with $\mathrm{MMO}-\mathrm{RuO}_{2} \mathrm{TiO}_{2}$ resulted in a significative increase in clopyralid transformation from $17.1 \%$ (from EC degradation) to $54.9 \%$ (PhEC degradation), while for the BDD anode the improvement was even more significant (from $16.6 \%$ for EC to $88.3 \%$ for PhEC degradation). These improvements can be a result of the contribution of mediated oxidation in the bulk solution. Then, when UV-C light irradiates the solution, chlorine and hydroxyl radicals can be formed by a homolytic homogeneous reaction (Eq. 13) in the bulk solution [33, 34]. Also, it is worthy of mentioning that the irradiation of photoactive materials, such as $\mathrm{TiO}_{2}$ (present in the anode surface) can affect the efficiency of clopyralid removal through the formation of $\mathrm{Cl}^{\bullet}$ radicals (Eq. 14) [35].

$\mathrm{HClO}^{-}+\mathrm{h} v \rightarrow \mathrm{Cl}^{\bullet}+{ }^{\bullet} \mathrm{OH}$

$\mathrm{TiO}_{2}-\mathrm{h}_{\mathrm{vb}+}+\mathrm{Cl}^{-} \rightarrow \mathrm{TiO}_{2}-\mathrm{Cl}^{\bullet}$

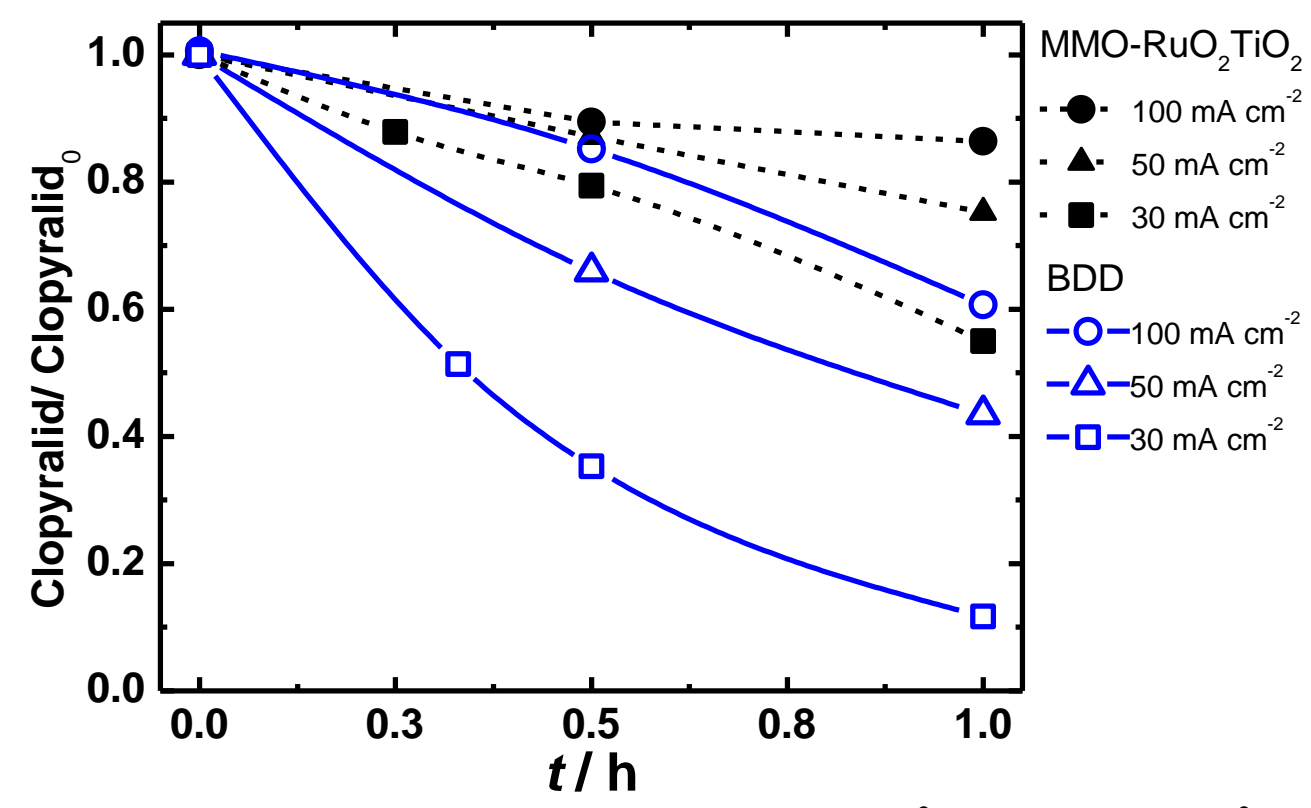

Figure 3. Clopyralid removal in $\mathrm{PhEC}$ degradation at $30 \mathrm{~mA} \mathrm{~cm}^{-2}(\bullet, \circ), 50 \mathrm{~mA} \mathrm{~cm}^{-2}(\boldsymbol{\Lambda}, \Delta)$ and 100

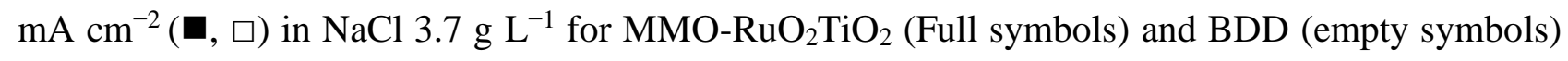
anodes. 
Once clarified the role of anodes on the electrochemical oxidation process in the removal of clopyralid, and that lowering current density increases the efficiency of the process, extensive EC and PhEC were carried out for a longer period of $8 \mathrm{~h}\left(6.4 \mathrm{~A} \mathrm{~h} \mathrm{~L}^{-1}\right)$ for a higher degree of clopyralid transformation.

Figure 4 shows clopyralid removal during 8 h of EC (Figure 4a) and PhEC degradation (Figure 4b) at a fixed current density of $30 \mathrm{~mA} \mathrm{~cm}{ }^{-2}$ in $\mathrm{NaCl} 3.7 \mathrm{~g} \mathrm{~L}^{-1}$ for all anodes. $\mathrm{MMO}-\mathrm{RuO}_{2} \mathrm{TiO}_{2}$ and $\mathrm{BDD}$ presented better efficiencies in both systems.
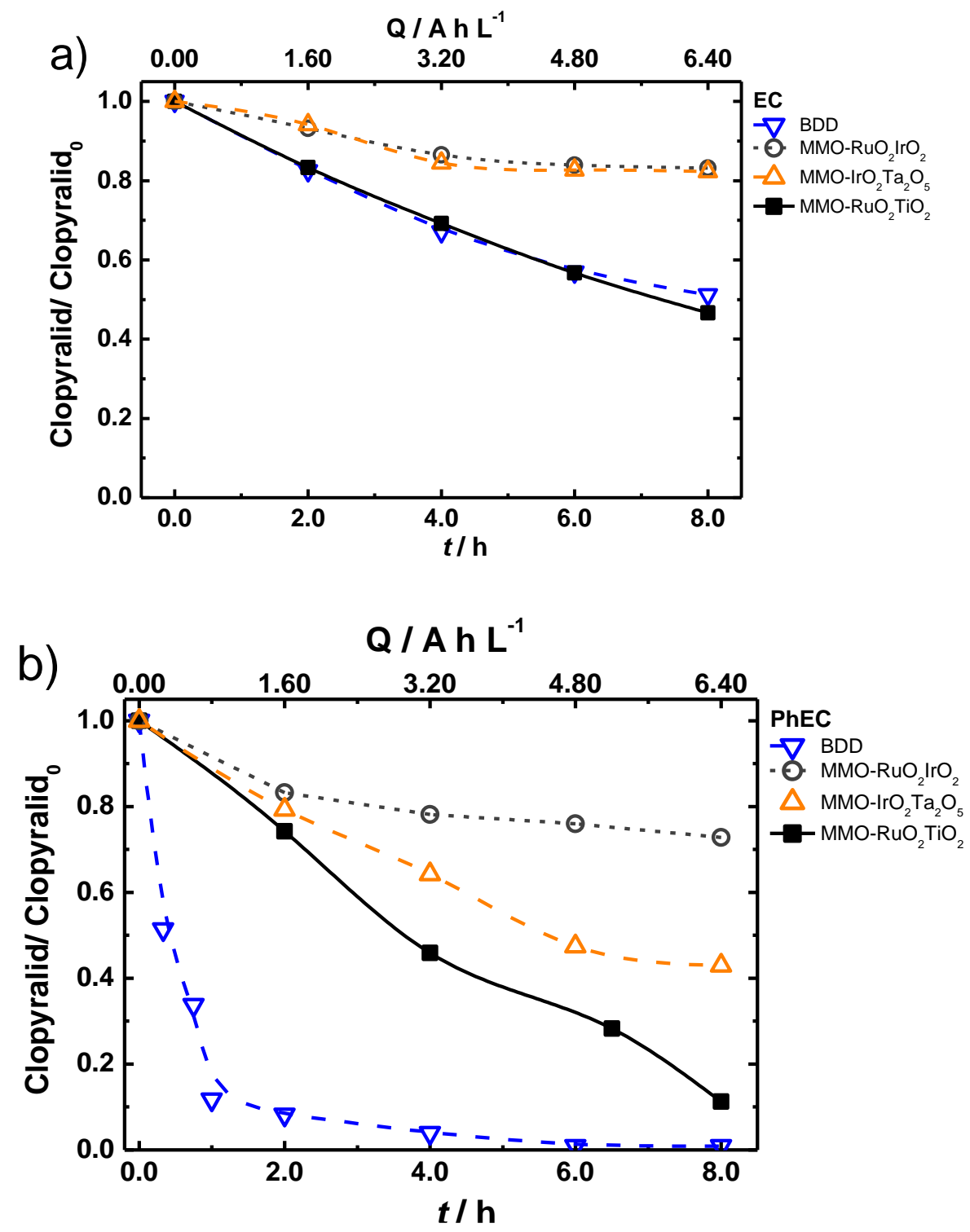

Figure 4. Clopyralid removal in electrochemical (EC) (a) and photoelectrochemical (PhEC) (b) at a fixed current density of $30 \mathrm{~mA} \mathrm{~cm}{ }^{-2}$ in $\mathrm{NaCl}\left(3.7 \mathrm{~g} \mathrm{~L}^{-1}\right)$ for all anodes. 
At this point, we point out that, due to the relevance of $\mathrm{Na}_{2} \mathrm{SO}_{4}\left(3.0 \mathrm{~g} \mathrm{~L}^{-1}\right)$ as a supporting 315 electrolyte, we also carried out EC and $\mathrm{PhEC}$ degradation experiments at $30 \mathrm{~mA} \mathrm{~cm}{ }^{-2}$ in order to 316 compare the behavior of the $\mathrm{MMO}-\mathrm{RuO}_{2} \mathrm{TiO}_{2}$ and BDD anodes during clopyralid removal in both

processes. As can be observed in Figure S4, BDD was much more effective than MMO in this medium, regardless of the process employed. It is an expected result, considering that BDD is known to generate large amounts of hydroxyl radicals, whereas much lower amounts of reactive ${ }^{\bullet} \mathrm{OH}$ are formed on the surface of the MMO anodes. In comparing the EC with PEC results, significant differences in the efficiencies can be observed. Note that for the MMO, the use of UV-C improved the clopyralid removal by almost $30 \%$. By contrast, when UV-C light is coupled to electrochemical degradation with BDD, worse results were observed.

To explain this unexpected antagonistic behavior, it must be considered that when using BDD, a large amount of ${ }^{\bullet} \mathrm{OH}$, instead of attacking organic species, may combine and form less reactive species according to reactions $15-19$ [36].

$2 \cdot \mathrm{OH} \rightarrow \mathrm{H}_{2} \mathrm{O}_{2}$

$$
\bullet \mathrm{OH}+\left(\mathrm{SO}_{4}^{-}\right)^{\bullet} \rightarrow \mathrm{HSO}_{5}^{-}
$$

$$
\mathrm{H}_{2} \mathrm{O}_{2} \rightarrow \mathrm{H}_{2} \mathrm{O}+0.5 \mathrm{O}_{2}
$$

$$
\mathrm{HSO}_{5}^{-} \rightarrow \mathrm{HSO}_{4}^{-}+0.5 \mathrm{O}_{2}
$$

$$
\mathrm{HSO}_{4}^{-}+{ }^{\bullet} \mathrm{OH} \rightarrow \mathrm{SO}_{4}^{-}+\mathrm{H}_{2} \mathrm{O}
$$

These reactions compete with the oxidation of pollutants, which points out that the nature of the pollutant may play an essential role in the efficiency of the combined process. The uncertainty in the positive synergism or antagonisms of coupling UV-C irradiation to BDD has already been reported [36, 37]. However, for some pollutants, this behavior is not well understood in the literature. Further studies should be performed focusing on the effect of the nature of the pollutant on the efficiency of photoelectrochemical degradation with BDD. 
339 the possible application of an electrochemical-based technology and it is shown in Figure 5. As seen, 340 the SEC increases for PhEC-BDD in both electrolytes, which indicates that from the energy point of 341 view the integration of technologies is not showing a clear advantage. In addition, the higher reactivity 342 in supporting electrolytes containing chlorides help to explain the lower energy consumption 343 observed.

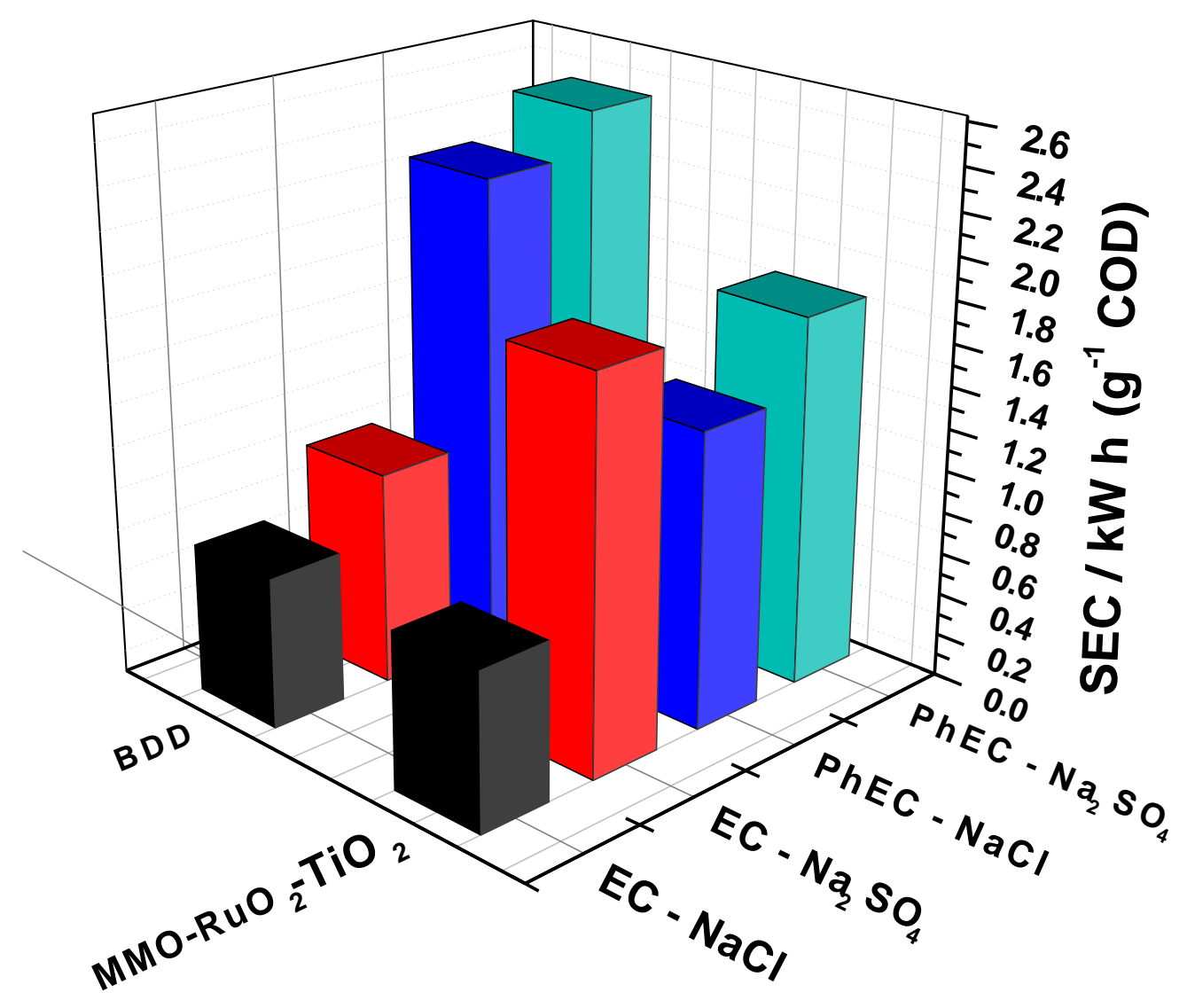

Figure 5. Specific energy consumption for the electrochemical (EC) and photoelectrochemical (PhEC) processes carried out at $30 \mathrm{~mA} \mathrm{~cm}{ }^{-2}$ in $\mathrm{NaCl}\left(3.7 \mathrm{~g} \mathrm{~L}^{-1}\right)$ or $\mathrm{Na}_{2} \mathrm{SO}_{4}\left(3.0 \mathrm{~g} \mathrm{~L}^{-1}\right)$ by using $\mathrm{MMO}-\mathrm{RuO}_{2} \mathrm{TiO}_{2}$ and BDD anodes. 
351 From this point, EC and PhEC degradation at $\mathrm{MMO}-\mathrm{RuO}_{2} \mathrm{TiO}_{2}$ and $\mathrm{BDD}$ anodes will be denoted as 352 EC-MMO, PhEC-MMO, EC-BDD, and PhEC-BDD, as only these technologies are going to be 353 compared. Short-term biodegradability tests were carried through the measurements of the dissolved oxygen uptake of non-acclimated activated sludge when in contact with treated samples (Figure S5). The biodegradability of wastewater is commonly evaluated in terms of the BOD to COD ratio. Thus, the biodegradability of untreated and treated clopyralid solutions was evaluated to show the feasibility of the biological process as post-treatment. The short-term biodegradability of the untreated solution was found to be as low as $8.3 \%$. Figure 6 shows the effect of electrochemical (EC) and

(Figure 6a) and on the biodegradability (Figure 6b) at a current density of $30 \mathrm{~mA} \mathrm{~cm}{ }^{-2}$. COD removals (Figure 6a) show that EC-BDD was capable of removing COD more efficiently, followed by PhEC-MMO. The PhEC-BDD and EC-MMO were less efficient conditions. However, biodegradability was improved differently according to anode material in both EC and PhEC treatments. Thus, Figure $6 \mathbf{b}$ notably shows that PhEC-MMO was capable of transforming clopyralid into more biodegradable by-products, such as short-chain carboxylic acids (Table 2), leading to a sample with higher biodegradability. Notably, the formation of carboxylic acids increased after the photoelectrochemical degradation process, being more pronounced in chloride media. It means that clopyralid is converted into more biodegradable compounds in the mediated process, as previously stated, due to the action of $\mathrm{Cl}^{\bullet}$ and ${ }^{\bullet} \mathrm{OH}$ in the bulk solution. 

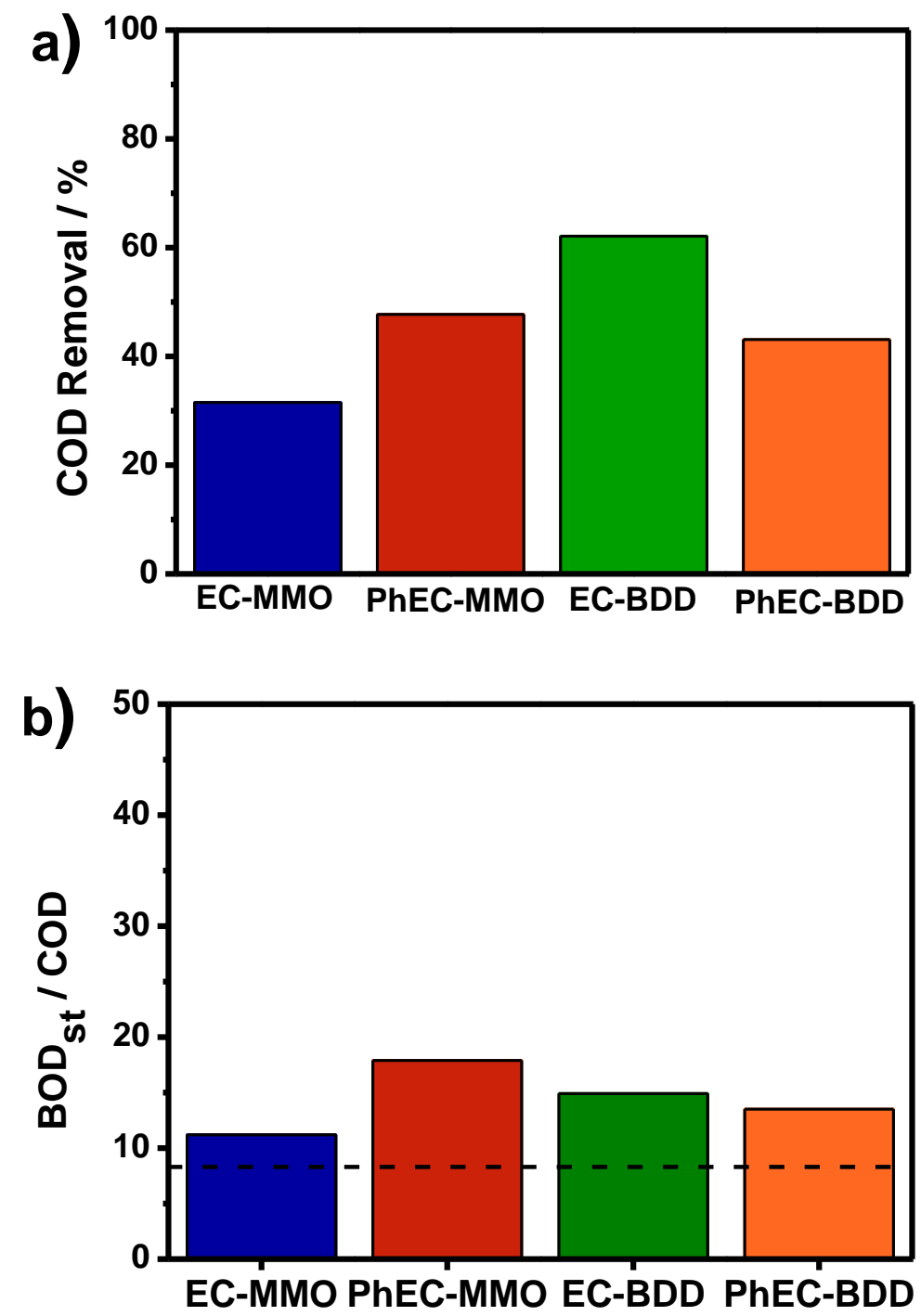

372 Figure 6. Effect of electrochemical (EC) and photoelectrochemical (PhEC) degradation on a) COD

373 removal after $8 \mathrm{~h}$ of treatment and b) biodegradability. Conditions: $\mathrm{pH}$ : 3.4; Clopyralid 0 : $100 \mathrm{mg} \mathrm{L}^{-1}$; 374 current density: $30 \mathrm{~mA} \mathrm{~cm}{ }^{-2}$, electrolyte: $\mathrm{NaCl}\left(3.7 \mathrm{mg} \mathrm{L}^{-1}\right)$. The dashed line indicates BODst/COD 375 of the untreated solution.

377 Figure 7 shows the effect of electrochemical (EC) and photoelectrochemical (PhEC) degradation on $378 \mathrm{COD}$ removal after $8 \mathrm{~h}$ of treatment in $\mathrm{Na}_{2} \mathrm{SO}_{4}\left(3.0 \mathrm{~g} \mathrm{~L}^{-1}\right)$ (Figure 7a) and on the biodegradability 379 (Figure 7b) at a current density of $30 \mathrm{~mA} \mathrm{~cm}^{-2}$. 

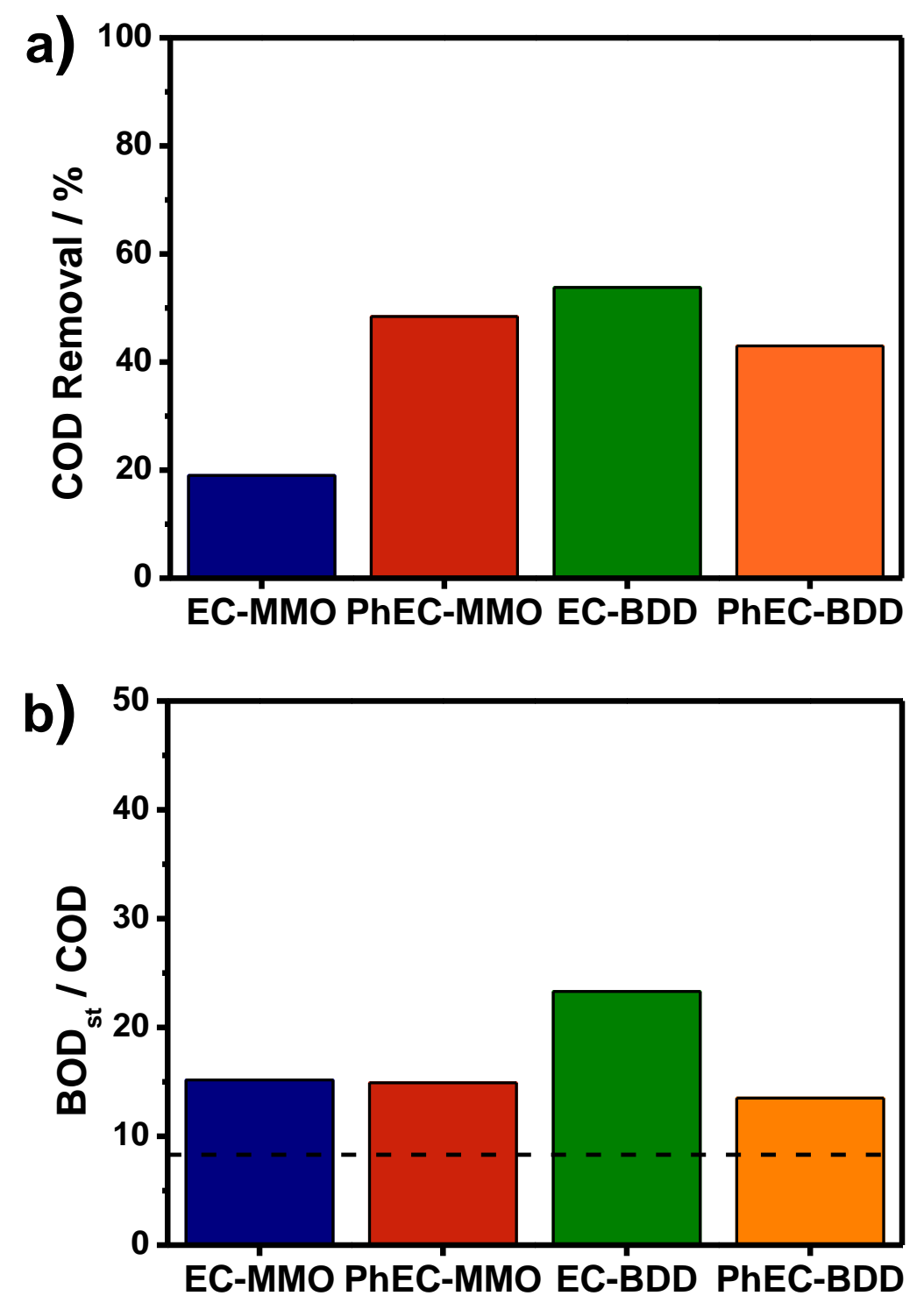

Figure 7. Effect of electrochemical (EC) and photoelectrochemical (PhEC) degradation on COD removal after $8 \mathrm{~h}$ of treatment in a) $\mathrm{Na}_{2} \mathrm{SO}_{4}\left(3.0 \mathrm{~g} \mathrm{~L}^{-1}\right)$ and b) biodegradability. Conditions: $\mathrm{pH}$ : 3.4; Clopyralid $_{0}$ : $100 \mathrm{mg} \mathrm{L}^{-1}$; current density: $30 \mathrm{~mA} \mathrm{~cm}^{-2}$. The dashed line indicates BODst/COD of the untreated solution.

A higher percentage of biodegradability of $23.3 \%$ (Figure 7b) is observed for EC-BDD. However, when UV-C is irradiated, the biodegradability decreases to $13.5 \%$. It may indicate that more refractory by-products should be formed during PhEC degradation. Regarding the MMO anode, a slight from $15.2 \%$, for the EC degradation, to $14.9 \%$ of biodegradability after PhEC degradation 
391 indicates that for $\mathrm{Na}_{2} \mathrm{SO}_{4}$ medium, the MMO is not efficient to improve the biodegradability of the 392 final waste.

393

Table 2. Obtained values for COD, total carboxylic acids, short term biodegradability for the samples 395 after $8 \mathrm{~h} \mathrm{EC}$, and PhEC degradations. $\mathrm{COD}_{0}=130 \mathrm{mg} \mathrm{O}_{2} \mathrm{~L}^{-1}$.

\begin{tabular}{|c|c|c|c|c|c|}
\hline Process & $\begin{array}{l}\text { Supporting } \\
\text { electrolyte }\end{array}$ & $\begin{array}{l}\text { Total carboxylic acids } \\
\qquad \text { (HPLC area) }\end{array}$ & $\mathrm{BOD}_{\text {st }}$ & $\begin{array}{c}\mathrm{COD} \\
\left(\mathrm{mg} \mathrm{O}_{2}\right. \\
\left.\mathrm{L}^{-1}\right)\end{array}$ & $\begin{array}{l}\text { Biodegradability } \\
\left(\mathrm{BOD}_{\mathrm{st}} / \mathrm{COD}\right)\end{array}$ \\
\hline EC-MMO & & 1724.2 & 0.5 & 89 & 11.2 \\
\hline EC-BDD & $\mathrm{Cl}^{-}$ & 843.2 & 0.4 & 49 & 16.3 \\
\hline PhEC-MMO & & 4444.3 & 0.5 & 67 & 17.9 \\
\hline PhEC-BDD & & 4987.1 & 0.5 & 74 & 13.5 \\
\hline EC-MMO & & 121.0 & 0.8 & 105.3 & 15.2 \\
\hline EC-BDD & $\mathrm{SO}_{4}{ }^{2-}$ & 2015.0 & 0.7 & 60 & 23.3 \\
\hline PhEC-MMO & & 197.3 & 0.5 & 67 & 14.9 \\
\hline PhEC-BDD & & 982.8 & 0.5 & 74 & 13.5 \\
\hline
\end{tabular}

\subsection{Toxicity Assessment}

398 Figure 8 presents the effect of electrochemical (EC) and photoelectrochemical (PhEC) process on 399 toxicity of treated clopyralid solutions at $30 \mathrm{~mA} \mathrm{~cm}^{-2}$ in $\mathrm{NaCl}\left(3.7 \mathrm{~g} \mathrm{~L}^{-1}\right)$ (Figure 8a) and $\mathrm{Na}_{2} \mathrm{SO}_{4}$ $400\left(3.0 \mathrm{~g} \mathrm{~L}^{-1}\right)$ (Figure 8b) by using $\mathrm{MMO}-\mathrm{RuO}_{2} \mathrm{TiO}_{2}$ and $\mathrm{BDD}$ anodes using the bioluminescent marine 401 bacteria Vibrio fisheri. Part a shows that at the initial stage of the degradation $\left(0.8 \mathrm{~A} \mathrm{~h} \mathrm{~L}^{-1}\right)$ in $\mathrm{NaCl}$ 402 medium, the toxicity is still high. However, extending the treatments for $8 \mathrm{~h}\left(6.4 \mathrm{~A} \mathrm{~h} \mathrm{~L}^{-1}\right)$, the bacteria 403 inhibition is significantly reduced to $29.1 \%$ after EC-MMO and $34.2 \%$ for PhEC-MMO, after $8 \mathrm{~h}$ of 404 treatment just in the case of $\mathrm{MMO}-\mathrm{RuO}_{2} \mathrm{TiO}_{2}$. It means that the toxicity of the treated solutions can 405 be quite different depending on the anode material. On the contrary, EC-BDD and PhEC-BDD 
resulted in total inhibition even at lower dilution values. It suggests that by-products formed during $\mathrm{EC}$ and $\mathrm{PhEC}$ at BDD at these conditions possibly favor the formation of by-products as toxic as the initial clopyralid solution.

For comparison purposes, the experiments were also conducted in $\mathrm{Na}_{2} \mathrm{SO}_{4}\left(3.0 \mathrm{~g} \mathrm{~L}^{-1}\right)$ (Figure 8b) as supporting electrolyte to investigate the behavior of both anodes during clopyralid transformation. In the presence of $\mathrm{Na}_{2} \mathrm{SO}_{4}$, the electrochemical oxidation at BDD anode presents the lower inhibition effect of $26.8 \%$, while a higher inhibition of $87.5 \%$ is obtained for the PhEC process. As compared to the results obtained in $\mathrm{NaCl}$ media, EC-BDD in $\mathrm{Na}_{2} \mathrm{SO}_{4}$ shows better outcomes in terms of efficiency and COD removal, as seen in Figure 7. Thus, the higher degree of COD removal in $\mathrm{Na}_{2} \mathrm{SO}_{4}$ seems to favor a reduction in the toxicity. For $\mathrm{MMO}-\mathrm{RuO}_{2} \mathrm{TiO}_{2}$ anode, $35.2 \%$ of inhibition is obtained after $8 \mathrm{~h}$ of EC-MMO treatment, while $64.2 \%$ is the inhibition measured for PhEC-MMO. These data point out that when coupling UV-C light irradiating $\mathrm{Na}_{2} \mathrm{SO}_{4}$ solution containing $100 \mathrm{mg}$ $\mathrm{L}^{-1}$ clopyralid, oxidants are activated in a distinct way than those in chloride medium.

In order to better understand the electrolyte effect, experiments were performed to evaluate the contribution of the oxidative species electrogenerated to the toxicity, putting under electrolysis the $\mathrm{NaCl}$ and $\mathrm{Na}_{2} \mathrm{SO}_{4}$ solutions in the absence of the contaminant. $\mathrm{NaCl}$ and $\mathrm{Na}_{2} \mathrm{SO}_{4}$ electrolyte solutions (in the absence of the contaminant) prior electrolysis does not generate significant inhibitory effects being non-toxic to the organism. However, after $8 \mathrm{~h}$ electrolysis in $\mathrm{NaCl}$ media $\left(6.4 \mathrm{~A} \mathrm{~h} \mathrm{~L}^{-1}\right)$, the inhibition value is $100 \%$ for EC-MMO. This outcome comes from the electrogenerated active chlorine (such as hypochlorite/hypochlorous) that was continuously accumulated in the solution during the $8 \mathrm{~h}$ of electrolysis in the $\mathrm{MMO}-\mathrm{RuO}_{2} \mathrm{TiO}_{2}$ case. For BDD anode, at the same condition, $23.5 \%$ of inhibition is seen. Small amounts of hypochlorite/hypochlorous are expected.

In contrast, chlorate and perchlorate species are the species mainly reported after electrolysis of $\mathrm{NaCl}$ using a BDD anode. For the $\mathrm{Na}_{2} \mathrm{SO}_{4}$ solution, the inhibitory effect was only $20.7 \%$ for MMO$\mathrm{RuO}_{2} \mathrm{TiO}_{2}$ and $46.1 \%$ for BDD. These results point out that electrolyte solution may influence the inhibitory effect after treatments. Remarkably, the final treated solutions containing $\mathrm{NaCl}$ with 
MMO- $\mathrm{RuO}_{2} \mathrm{TiO}_{2}$ presented reduced toxicity, which suggests that hypochlorite concentration substantially decreases at the end of treatment due to the reaction with the clopyralid molecule.

Considering that the formation of chlorates and perchlorates may be different in the presence of clopyralid, these species were quantified after the electrochemical oxidation with and without clopyralid. After the electrolysis of a chloride solution using the BDD, the chlorates and perchlorates were found at the concentrations of $1582.2 \mathrm{ppm}$ and $233.35 \mathrm{ppm}$, respectively. Meanwhile for MMO electrolysis, this value was $62.3 \mathrm{ppm}$ for chlorates, while no perchlorate was detected. In the presence of clopyralid, the values found for chlorates and perchlorates increased to $2346.7 \mathrm{ppm}$ and $345.4 \mathrm{ppm}$, respectively. The same trend was observed using the MMO anode with chlorates concentration of $217.1 \mathrm{ppm}$, and again without perchlorate. The significant increase in the amount of chlorates and perchlorates in the treated solutions with $\mathrm{BDD}$ has to be explained by the high reactivity of the electrogenerated ${ }^{\bullet} \mathrm{OH}$ radicals with chloride ions. In the treatment of solutions containing clopyralid, besides chlorides contained in the electrolyte, more chlorides can come after their release from the clopyralid molecule during degradation. Taking this into account, the increase in the hazardous chlorates and perchlorates for EC/PhEC-BDD may play an essential role in the inhibitory effect observed in Figure 8a.

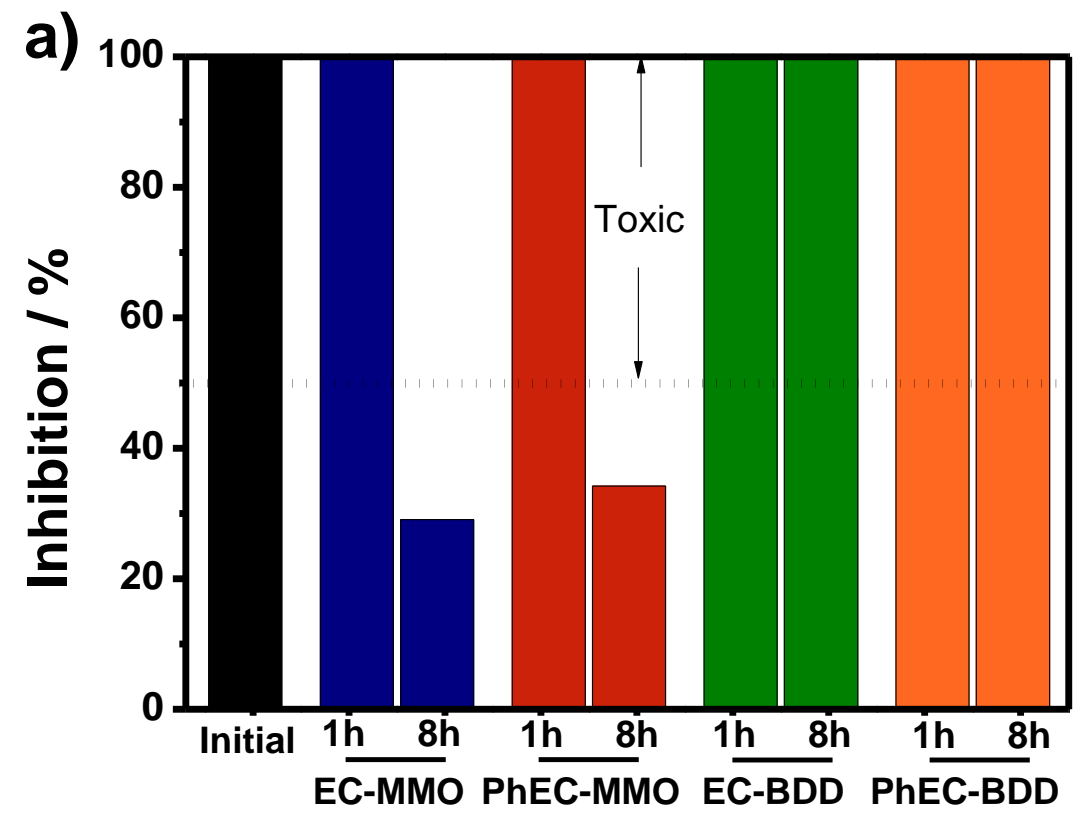




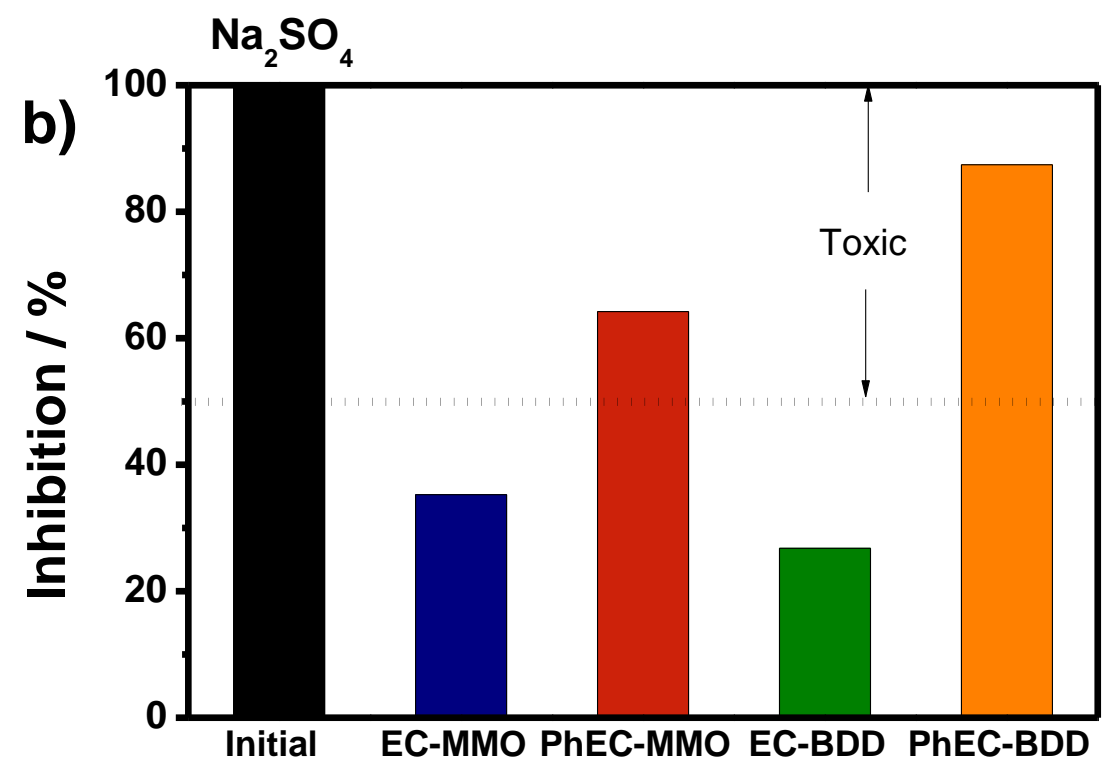

Figure 8. Effect of electrochemical (EC) and photoelectrochemical (PhEC) process on the toxicity of treated clopyralid solutions at $30 \mathrm{~mA} \mathrm{~cm}^{-2}$ in $\mathrm{NaCl}\left(3.7 \mathrm{~g} \mathrm{~L}^{-1}\right)$ a) and $\mathrm{Na}_{2} \mathrm{SO}_{4}\left(3.0 \mathrm{~g} \mathrm{~L}^{-1}\right)$ b) by using $\mathrm{MMO}-\mathrm{RuO}_{2} \mathrm{TiO}_{2}$ and $\mathrm{BDD}$ anodes using the bioluminescent marine bacteria Vibrio fisheri. Conditions: Clopyralid 0 : $100 \mathrm{mg} \mathrm{L}^{-1}$; current density: $30 \mathrm{~mA} \mathrm{~cm}{ }^{-2}$.

The results here obtained are quite impressive, considering a matrix containing chlorides. The reduced toxicity and improved biodegradability for EC-MMO and PhEC-MMO degradation highlight the use of $\mathrm{MMO}-\mathrm{RuO}_{2} \mathrm{TiO}_{2}$ as anode material capable of transforming clopyralid into by-products more biodegradable and less toxic for a post-treatment by conventional biological treatment.

\section{Conclusions}

Based on the results obtained from this research, the following conclusions are drawn:

- Results from the electrochemical characterization of anodes materials revealed that MMO$\mathrm{RuO}_{2} \mathrm{IrO}_{2}$ presented higher voltammetric charges while possesses low OEP. Meanwhile, BDD and $\mathrm{MMO}-\mathrm{IrO}_{2} \mathrm{Ta}_{2} \mathrm{O}_{5}$ presented the highest overpotential for OEP, which affects the electrochemical degradation systems directly.

- The optimal current density of $30 \mathrm{~mA} \mathrm{~cm}^{-2}$ was found for both electrochemical and photoelectrochemical degradation regardless of the anode material. 
- Photoelectrochemical degradation was the most efficient at low applied electric charges (6.4 A h L ${ }^{-1}$ ) only when MMO- $\mathrm{RuO}_{2} \mathrm{TiO}_{2}$ anode is used, which can be explained in terms of the different mechanism of formation of hydroxyl radicals through a homolytic homogenous reaction in bulk, resulting in the improvement of biodegradability of the final sample.

- Toxicity assays pointed out significant differences. For both processes using MMO$\mathrm{RuO}_{2} \mathrm{TiO}_{2}$, lower toxicity was found when compared to BDD anode. Finally, the MMO$\mathrm{RuO}_{2} \mathrm{TiO}_{2}$ showed to be suitable for electrochemical and photoelectrochemical degradation of clopyralid in solutions containing chlorides being competitive with a BDD anode as a pretreatment before biological treatment.

\section{Acknowledgments}

Financial support from the Agencia Estatal de Investigación and European Union through project CTM2016-76197-R (AEI/FEDER, UE) is gratefully acknowledged and the Brazilian agencies (Conselho Nacional de Desenvolvimento Científico e Tecnológico - CNPq grants 304419/2015-0, 305438/2018-2, and 310282/2013-6), Coordenação de Aperfeiçoamento de Pessoal de Nível Superior - CAPES (88882.365552. /2018-01 and 88881.187890/2018-01) and FAPITEC/SE.

\section{References}

[1] M.A Rodrigo, N. Oturan, M.A. Oturan, Electrochemically assisted remediation of pesticides in soils and water: a review, Chem. Rev. 114(17) (2014) 8720-8745.

[2] M.J.M. de Vidales, M.P. Castro, C. Saez, P. Cañizares, M.A. Rodrigo, Radiation-assisted electrochemical processes in semi-pilot scale for the removal of clopyralid from soil washing wastes, Sep. Purif. Technol. 208 (2019) 100-109.

[3] A. Özcan, N. Oturan, Y. Şahin, M.A. Oturan, Electro-Fenton treatment of aqueous clopyralid solutions, International J. Environ. Anal. Chem. 90(3-6) (2010) 478-486.

[4] C. Berberidou, V. Kitsiou, S. Karahanidou, D.A. Lambropoulou, A. Kouras, C.I. Kosma, T.A. Albanis, I. Poulios, Photocatalytic degradation of the herbicide clopyralid: kinetics, degradation pathways and ecotoxicity evaluation, J. Chem. Technol. Biot. 91(9) (2016) 2510-2518. 
[5] I. Oller, S. Malato, J. Sánchez-Pérez, Combination of advanced oxidation processes and biological treatments for wastewater decontamination-a review, Sci. Total. Environ. 409(20) (2011) 4141-4166.

[6] M.B. Carboneras, P. Cañizares, M.A. Rodrigo, J. Villaseñor, F.J. Fernandez-Morales, Improving biodegradability of soil washing effluents using anodic oxidation, Bioresource Technol. 252 (2018) 1-6.

[7] O. Ganzenko, D. Huguenot, E.D. Van Hullebusch, G. Esposito, M.A. Oturan, Electrochemical advanced oxidation and biological processes for wastewater treatment: a review of the combined approaches, Environ. Sci. Pollut. R. 21(14) (2014) 8493-8524.

[8] C.A. Martinez-Huitle, M.A. Rodrigo, I. Sires, O. Scialdone, Single and coupled electrochemical processes and reactors for the abatement of organic water pollutants: a critical review, Chem. Rev. 115(24) (2015) 13362-13407.

[9] D.A. Coledam, M.M. Pupo, B.F. Silva, A.J. Silva, K.I. Eguiluz, G.R. Salazar-Banda, J.M. Aquino, Electrochemical mineralization of cephalexin using a conductive diamond anode: A mechanistic and toxicity investigation, Chemosphere 168 (2017) 638-647.

[10] S. Cotillas, L. Cañizares, M. Muñoz, C. Sáez, P. Cañizares, M.A. Rodrigo, Is it really important the addition of salts for the electrolysis of soil washing effluents?, Electrochimica Acta 246 (2017) 372-379.

[11] C.A. Martínez-Huitle, M. Panizza, Electrochemical oxidation of organic pollutants for wastewater treatment, Current Opinion in Electrochemistry 11 (2018) 62-71.

[12] F. Sopaj, M.A. Rodrigo, N. Oturan, F.I. Podvorica, J. Pinson, M.A. Oturan, Influence of the anode materials on the electrochemical oxidation efficiency. Application to oxidative degradation of the pharmaceutical amoxicillin, Chem. Eng. J. 262 (2015) 286-294.

[13] C. Ridruejo, F. Centellas, P.L. Cabot, I. Sirés, E. Brillas, Electrochemical Fenton-based treatment of tetracaine in synthetic and urban wastewater using active and non-active anodes, Water Res. 128 (2018) 71-81.

[14] M.O. Santos, G. de OS Santos, S. Mattedi, S. Griza, K.I. Eguiluz, G.R. Salazar-Banda, Influence of the calcination temperature and ionic liquid used during synthesis procedure on the physical and electrochemical properties of $\mathrm{Ti} /\left(\mathrm{RuO}_{2}\right)_{0.8}-\left(\mathrm{Sb}_{2} \mathrm{O}_{4}\right)_{0.2}$ anodes, J. Electroanal. Chem. 829 (2018) 116-128.

[15] G. Santos, L. Silva, Y. Alves, R. Silva, K. Eguiluz, G. Salazar-Banda, Enhanced stability and electrocatalytic properties of $\mathrm{Ti} / \mathrm{Ru}_{\mathrm{x}} \mathrm{Ir}_{1-\mathrm{x}} \mathrm{O}_{2}$ anodes produced by a new laser process, Chem. Eng. J. 355 (2019) 439-447. 
[16] G.O. Santos, K.I. Eguiluz, G.R. Salazar-Banda, C. Saez, M.A. Rodrigo, Photoelectrolysis of clopyralid wastes with a novel laser-prepared $\mathrm{MMO}-\mathrm{RuO}_{2} \mathrm{TiO}_{2}$ anode, Chemosphere (2019) 125455.

[17] L.M. da Silva, G.d.O.S. Santos, M.M. de Salles Pupo, K.I.B. Eguiluz, G.R. Salazar-Banda, Influence of heating rate on the physical and electrochemical properties of mixed metal oxides anodes synthesized by thermal decomposition method applying an ionic liquid, J. Electroanal. Chem. 813 (2018) 127-133.

[18] S.O. Ganiyu, C.A. Martínez-Huitle, Nature, Mechanisms and Reactivity of Electrogenerated Reactive Species at Thin-Film Boron-Doped Diamond (BDD) Electrodes During Electrochemical Wastewater Treatment, ChemElectroChem 6(9) (2019) 2379-2392.

[19] L. Rizzo, Bioassays as a tool for evaluating advanced oxidation processes in water and wastewater treatment, Water Res. 45(15) (2011) 4311-4340.

[20] I. Sirés, E. Brillas, M.A. Oturan, M.A. Rodrigo, M. Panizza, Electrochemical advanced oxidation processes: today and tomorrow. A review, Environ. Sci. Pollut. R. 21(14) (2014) 8336-8367.

[21] F.C. Moreira, R.A. Boaventura, E. Brillas, V.J. Vilar, Electrochemical advanced oxidation processes: a review on their application to synthetic and real wastewaters, Appl. Catal., B. 202 (2017) 217-261.

[22] M. Zaghdoudi, F. Fourcade, I. Soutrel, D. Floner, A. Amrane, H. Maghraoui-Meherzi, F. Geneste, Direct and indirect electrochemical reduction prior to a biological treatment for dimetridazole removal, J. Hazard. Mater. 335 (2017) 10-17.

[23] J.R. Silva, D.S. Santos, U.R. Santos, K.I. Eguiluz, G.R. Salazar-Banda, J.K. Schneider, L.C. Krause, J.A. López, M.L. Hernández-Macedo, Electrochemical and/or microbiological treatment of pyrolysis wastewater, Chemosphere 185 (2017) 145-151.

[24] D.S. Vilar, G.O. Carvalho, M.M. Pupo, M.M. Aguiar, N.H. Torres, J.H. Américo, E.B. Cavalcanti, K.I. Eguiluz, G.R. Salazar-Banda, M.S. Leite, Vinasse degradation using Pleurotus sajor-caju in a combined biological-Electrochemical oxidation treatment, Sep. Purif. Technol 192 (2018) 287-296.

[25] I. Gonzaga, A. Andrade, R. Silva, G. Salazar-Banda, E. Cavalcanti, K. Eguiluz, Synthesis of high-area chemically modified electrodes using microwave heating, Chem. Eng. Comm. 206(5) (2019) 647-653.

[26] M. Panizza, P. Michaud, G. Cerisola, C. Comninellis, Electrochemical treatment of wastewaters containing organic pollutants on boron-doped diamond electrodes: Prediction of specific energy consumption and required electrode area, Electrochem. Commun. 3(7) (2001) 336-339.

[27] C. Comninellis, C. Pulgarin, Anodic oxidation of phenol for waste water treatment, J. Appl. Electrochem. 21(8) (1991) 703-708. 
[28] R. Palma-Goyes, J. Vazquez-Arenas, C. Ostos, A. Manzo-Robledo, I. Romero-Ibarra, J. Calderón, I. González, In search of the active chlorine species on $\mathrm{Ti} / \mathrm{ZrO}_{2}-\mathrm{RuO}_{2}-\mathrm{Sb}_{2} \mathrm{O}_{3}$ anodes using DEMS and XPS, Electrochim. Acta 275 (2018) 265-274.

[29] F. Souza, C. Saéz, M.R. Lanza, P. Cañizares, M. Rodrigo, Removal of pesticide 2,4-D by conductive-diamond photoelectrochemical oxidation, Appl. Catal. B 180 (2016) 733-739.

[30] M.A Rodrigo, P. Michaud, I. Duo, M. Panizza, G. Cerisola, C. Comninellis, Oxidation of 4chlorophenol at boron-doped diamond electrode for wastewater treatment, J. Electrochem. Soc. 148(5) (2001) D60-D64.

[31] P. Canizares, M. Diaz, J. Dominguez, J. Garcia-Gomez, M. Rodrigo, Electrochemical oxidation of aqueous phenol wastes on synthetic diamond thin-film electrodes, Ind. Eng. Chem. Res. 41(17) (2002) 4187-4194.

[32] D. Dionisio, A.d.J. Motheo, C. Sáez, M. Rodrigo, Effect of the electrolyte on the electrolysis and photoelectrolysis of synthetic methyl paraben polluted wastewater, Sep. Purif. Technol. 208 (2019) 201-207.

[33] I. Sánchez-Montes, J.F. Pérez, C. Sáez, M.A. Rodrigo, P. Cañizares, J.M. Aquino, Assessing the performance of electrochemical oxidation using DSA ${ }^{\circledR}$ and BDD anodes in the presence of UVC light, Chemosphere 238 (2020) 124575.

[34] G. Hurwitz, P. Pornwongthong, S. Mahendra, E.M. Hoek, Degradation of phenol by synergistic chlorine-enhanced photo-assisted electrochemical oxidation, Chem. Eng. J. 240 (2014) 235243.

[35] C. Chen, C. Lu, Y. Chung, J. Jan, UV light induced photodegradation of malachite green on TiO2 nanoparticles, J. Hazard. Mater. 141(3) (2007) 520-528.

[36] M.J.Martín de Vidales, C. Sáez, J.F. Pérez, S. Cotillas, J. Llanos, P. Canizares, M.A. Rodrigo, Irradiation-assisted electrochemical processes for the removal of persistent organic pollutants from wastewater, J. Appl. Electrochem. 45(7) (2015) 799-808.

[37] M.J.Martín de Vidales, M. Millán, C. Sáez, P. Cañizares, M.A. Rodrigo, Irradiated-assisted electrochemical processes for the removal of persistent pollutants from real wastewater, Sep. Purif. Technol.175 (2017) 428-434. 